\title{
Tubular Discectomy Versus Conventional Microdiscectomy for the Treatment of Lumbar Disc Herniation: A Comparative Study
}

\author{
Sanjeev Asati, Sanyam Jain, Vishal G Kundnani \\ Department of Orthopaedics \& Spine Surgery, Bombay Hospital and Medical Research Centre, Mumbai, India
}

Corresponding Author:

Sanyam Jain, MD, MS

DDepartment of Orthopedics \& Spine

Surgery, Room No-128, Bombay

Hospital \& Medical Research Center,

12, New Marine Lines, Mumbai-400020,

Maharashtra, India

Tel: +919727776564

E-mail: jainsanyam933@gmail.com
Objective: The study aims to compare the outcomes of micro-lumbar discectomy (MLD) with tubular micro-endoscopic discectomy (MED). Methods: A retrospective analysis of 414 patients who underwent single-level lumbar discectomy either by tubular MED or MLD between 2008-2016 was performed. Demographics, surgical duration, intraoperative blood loss, total hospital stay, visual analogue scale (VAS) pain score, Oswestry disability index (ODI) score before and after the surgery and complications were evaluated between the groups. Results: Out of the 414 patients, 217 patients were treated with MLD and 197 by tubular MED. The mean age in MLD and tubular MED group was 44.7 and 42.4 years. There was a significant improvement in VAS and ODI scores at 2 weeks in both the groups, without any significant difference. Average surgical time was shorter and the average blood loss was higher in MLD as compared to the MED group. Average hospital stay in MED (1.03 days) was significantly less than MLD group (1.91 days). There were similar incidences of dural tear in both the groups, however, more patients had wound infection in the MLD group. Conclusion: Lumbar discectomy either by tubular MED or MLD are very safe and effective means of treating disc herniation related sciatic pain. Patients who underwent minimally invasive tubular micro-endoscopic discectomy were found to have similar outcomes as those of who underwent micro-lumbar discectomy. However, given the learning curve associated with minimally invasive approaches to clinical practice, these modest clinical benefits probably do not warrant the transition from a standard microsurgical approach to a minimally invasive approach.

Key Words: Dural tear, Lumbar disc prolapse, Micro-endoscopic discectomy (MED), Microlumbar discectomy (MLD)

\section{INTRODUCTION}

Lumbar disc prolapse is the most common spinal problem affecting young age group (30-50 years). Disc herniation causing radicular pain with or without neurological deficit and those refractory to conservative management for a minimum of 4 weeks, having their activities of daily living affected are dealt surgically ${ }^{12}$. Discectomy performed whether open or by minimally invasive technique remains the gold standard treatment of choice including hemilaminotomy, flavectomy and discectomy ${ }^{11,16,20)}$. The success rates of discectomy in the treatment of sciatic pain has been reported to range from $50-98 \% \%^{9}$.

Minimally invasive tubular lumbar micro-endoscopic discectomy (MED) is a refinement of the standard open micro-lumbar discectomy (MLD) technique. Traditional MLD surgery requires muscles dissection and retraction causing iatrogenic morbidity of the soft tissues but allows greater visualization of dural sac, direct visualization of anatomic structures and obtaining the optimal angle for disc removal, however, MED is associated with tubular retractors which minimizes the tissue injury and ensures that deeper tissues are less exposed to potential pathologic organisms due to restricted surgical field. Advantages of minimal invasive surgery includes less perioperative pain, early ambulation, shorter hospital stay and early return to work with smaller incision ${ }^{13,18,19)}$. Despite these claims there is little support in the literature to justify the adoption of MED over standard MLD and is still controversial.

In this study, we aimed to compare the surgical, clinical and functional results of micro-lumbar discectomy (MLD) with tubular 
micro-endoscopic discectomy (MED) and we believe that ours is the first study to compare these results in Indian subcontinent with a large series of patients.

\section{MATERIALS AND METHOD}

A retrospective analysis of 414 patients who underwent single-level lumbar discectomy either by tubular MED or MLD by a single surgeon at a single institute between 2008-2016 was performed. Approval from institutional review of board was taken. Patients with lumbar disc herniation having nerve root signs, correlating MRI findings and a trial of at least 6 weeks of conservative treatment were included. Demographic variables (age, sex, height, weight, and body mass index), perioperative parameters (operative time, estimated blood loss, length of hospital stay), pre-op and post-op VAS and ODI scores, and complications with need for admission to the hospital, percentage who required conversion to an open procedure were evaluated.

\section{Operative Procedure}

\section{1) Micro-endoscopic tubular discectomy}

Under general anaesthesia, the patient was positioned prone on a radiolucent table with bolsters below the chest and pelvis keeping the abdomen free, head on soft jelly pad with head end raised and pressure points well padded. Using AP/Lateral fluoroscopy imaging, $18 \mathrm{G}$ spinal needle inserted at the diseased level $1 \mathrm{~cm}$ lateral to midline at spino-laminar junction. $2 \mathrm{~cm}$ in-

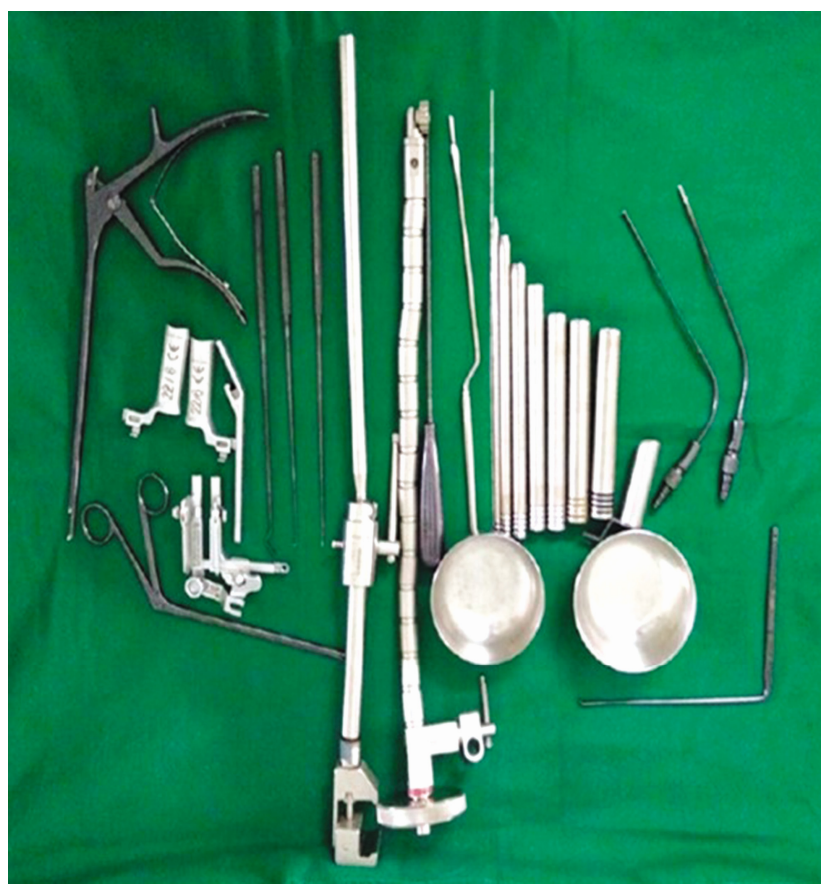

Fig. 1. Instruments with tubular set used in MED. cision kept at the needle site till the fascia and the blunt end of guide wire was inserted under fluoroscopic guidance at spino-laminar junction targeted at the centre of disc involved. The procedure carried out using METRx MED system (Medtronic Sofamor Danek Inc., Memphis, TN, USA) (Fig. 1). Sequential dilators were inserted over the guide wire separating the muscles and the final tubular retractor either $18 \mathrm{~mm}$ or $20 \mathrm{~mm}$ in diameter was docked. The operating microscope was then bought into field. Muscles covering the lamina were carefully resected and the bony structures were exposed. The midline was confirmed first by resecting the base of the spinous process with high speed burr of $4 \mathrm{~mm}$. A drill is then used to do a laminotomy down to the ligamentum flavum. The ligamentum is carefully removed with the combination of curettes and Kerrison rongeurs until the dura and nerve roots are identified. The thecal sac and nerve root shoulder are carefully retracted and the offending herniated disc is subsequently removed. The epidural bleeding was controlled using bipolar cautery or gelfoam with neurosurgical patty. Appropriate decompression is then confirmed by tactile feel with curette or nerve hook. The thoracolumbar fascia and subcutaneous tissue were closed by 2-0 vicryl suture. The skin was closed using 3-0 monocryl suture.

\section{2) Micro-lumbar discectomy}

Patient positioning is same as done in MED. First, we mark our site using $\mathrm{C}$-arm fluoroscopy in antero-posterior and lateral views for incision. A standard midline incision $\sim 4-5 \mathrm{~cm}$ in length kept in the midline towards the side of herniation. Dissection done through subcutaneous tissue, lumbodorsal fascia and then on to the spinous process of the affected area. A bladed retractor (McCullough retractor) (Fig. 2) was then inserted to maintain the surgical access. The operating microscope was then bought into field. A burr can be used to thin the lamina overlying the disc, if needed and a curette used to develop a plane on the underside of the remaining superior lamina and ligamentum

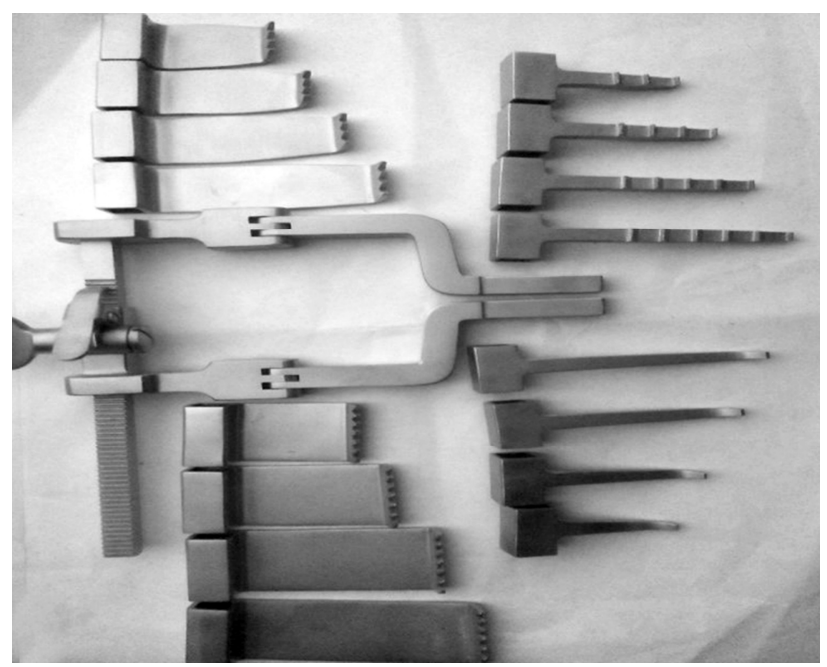

Fig. 2. Instruments with retractor set used in MLD. 
Table 1. Demographic variables of patients in both groups

\begin{tabular}{llll}
\hline Variables & \multicolumn{1}{c}{ MLD } & \multicolumn{1}{c}{ MED } & p-value \\
\hline Number of patients & 217 & 197 & NS ( $p$-value >0.05) \\
Age (years) & 44.7 & 42.4 & NS ( $p$-value $>0.05)$ \\
Sex (M:F) & $114: 103$ & $101: 96$ & 28.4 \\
Mean BMI & 27.3 & L3-4: 22 & L4-5: 74 \\
Levels operated & L3-4: 25 & L5-S1: 101 & NS ( $p$-value $>0.05)$ \\
& L4-5: 73 & 17.3 & \\
Follow-up period & L5-S1: 119 & 16.4 &
\end{tabular}

Table 2. Preoperative and Postoperative clinical parameters between both groups

\begin{tabular}{|c|c|c|c|c|c|c|c|c|c|}
\hline & \multicolumn{3}{|c|}{ VAS (leg pain) } & \multicolumn{3}{|c|}{ VAS (back pain) } & \multicolumn{3}{|c|}{ ODI } \\
\hline & Pre-op & $\begin{array}{l}\text { Post-op } \\
\text { (2 weeks) }\end{array}$ & $\begin{array}{c}\text { Post-op } \\
\text { (1 yr) }\end{array}$ & Pre-op & $\begin{array}{l}\text { Post-op } \\
\text { (2 weeks) }\end{array}$ & $\begin{array}{c}\text { Post-op } \\
(1 \text { yr) }\end{array}$ & Pre-op & $\begin{array}{l}\text { Post-op } \\
\text { (2 weeks) }\end{array}$ & $\begin{array}{c}\text { Post-op } \\
\text { (1 yr) }\end{array}$ \\
\hline MED & 7.2 & 1.65 & 1.70 & 3.07 & 1.02 & 1.26 & 37 & 15 & 13 \\
\hline MLD & 6.9 & 1.71 & 1.68 & 2.93 & 1.97 & 1.37 & 40 & 17 & 14 \\
\hline
\end{tabular}

VAS: visual analogue scale; ODI: oswestry disability index.

flavum. Bone and ligamentum flavum were then removed with Kerrison rongeurs to develop working window for discectomy, working proximally and laterally to free tethered ligamentum as needed. Gentle retraction of dura and nerve root using nerve root retractor was done and offending disc was removed using a pituitary or other micro-instrument. Closure done in layers.

In both the groups a single dose of intravenous antibiotic $\left(2^{\text {nd }}\right.$ generation cephalosporins) was given 30 minutes before starting the procedure as a standard protocol. all the patients were mobilised out of bed next day in the morning. Suture removal was done at 10-12 days post-surgery. back muscles strength exercises were started at 2 weeks. The patients were followed up at regular intervals of 2 weeks, 3 months, 6 months and yearly after that.

\section{Statistical Analysis}

Statistical analysis was performed using the SPSS software version 20.0 (SPSS Inc., Chicago, IL, USA). The groups were compared using the Student $t$-test for continuous variables and the chi-square test for categorical variables. A p-value of $<0.05$ was considered statistically significant.

\section{RESULTS}

Out of 414 patients, 217 were treated with MLD and 197 by tubular MED. The mean age in the MLD group was 44.7 years while it was 42.4 years in the MED group. There was no statistical difference in demographical data between the two groups. The mean follow-up period for MLD and MED group was 16.4 and 17.3 months (Table 1). There was a significant improvement in VAS and ODI scores at 2 weeks in both the groups. There
Table 3. Comparison of perioperative parameters between both groups

\begin{tabular}{lcc}
\hline \hline Variables & MED & MLD \\
\hline Operating time (mins) & 82.5 & 71.5 \\
EBL (mL) & 48.3 & 82.3 \\
Return to work (weeks) & 4.65 & 5.86 \\
Hospital stay (days) & 1.03 & 1.91 \\
\hline
\end{tabular}

EBL: estimated blood loss.

Table 4. Comparison of complications between both groups

\begin{tabular}{lcc}
\hline \hline Complications & MED (n) (\%) & MLD (n) (\%) \\
\hline Dural tear & $11(5.5 \%)$ & $10(4.6 \%)$ \\
Post op CSF leak & - & 5 \\
Residual disc & $4(2.03 \%)$ & $2(0.9 \%)$ \\
Infection & - & 11 \\
Postop-discitis & - & 3 \\
Neurological injury & 2 & 2 \\
Need for hospital admission & 5 & 17 \\
Conversion to open & 2 & -
\end{tabular}

was a greater reduction of back pain in the MED group at 2 weeks compared to MLD group but at 1 year both are comparable and not statistically significant (Table 2).

Average surgical time was significantly shorter in MLD (71.5 $\mathrm{min}$ ) as compared to MED group (82.5 min). the Average blood loss was significantly higher $(82.3 \mathrm{~mL})$ in MLD group as compared to MED group ( $48.3 \mathrm{~mL}$ ) (Table 3 ). Length of incision as measured from the surgical scar was $1.7 \mathrm{~cm}$ in MED while it was $3.0 \mathrm{~cm}$ in MLD group.

Average hospital length of stay in MED (1.03 days) which 
Sanjeev Asati, et al.

was significantly less than MLD group (1.91 days). Likewise, MLD group patients took 5.86 weeks to return to activity which was higher than the MED group (4.65 weeks).
There were 10 cases $(4.6 \%)$ of dural tear in MLD and 11 cases (5.5\%) in MED group. However, none of the patients showed post-operative CSF leak in MED group as compared to MLD

Table 5. Studies comparing results between tubular MED with Open (MLD)

\begin{tabular}{|c|c|c|c|c|}
\hline Study & Surgical technique & No of patients & Significant difference outcomes & $\begin{array}{c}\text { Non-significant difference } \\
\text { outcomes }\end{array}$ \\
\hline Arts et al. & $\begin{array}{l}\text { Tubular MED vs } \\
\text { microdiscectomy }\end{array}$ & 166 vs 159 & $\begin{array}{l}\text { Higher rate of recovery in open group at } \\
1 \text { year ( } 79 \text { vs } 69 \%) \text {. } \\
\text { Greater improvement in VAS leg and back } \\
\text { pain scores in the open group. } \\
\text { Longer operative time with tubular } \\
\text { discectomy. } \\
\text { MED associated with shorter hospital stay, } \\
\text { early time to mobilization and less } \\
\text { progression of motor/sensory deficits } \\
\text { postoperatively }\end{array}$ & $\begin{array}{l}\text { No significant difference in } \\
\text { complication rate, RDQ, } \\
\text { SF-36. } \\
\text { No significant difference at } 2 \\
\text { yrs follow-up in clinical } \\
\text { outcomes or reoperation } \\
\text { rates. }\end{array}$ \\
\hline $\begin{array}{l}\text { Harrington } \\
\text { et al. }\end{array}$ & MED vs open & 31 vs 35 & $\begin{array}{l}45.2 \% \text { of MED were discharged on the } \\
\text { same day vs } 5.75 \% \text { in the open group. } \\
\text { MED group used less intravenous } \\
\text { morphine and less hydrocodone and did } \\
\text { not used oxycodone for pain control. }\end{array}$ & $\begin{array}{l}\text { No difference in intraoperative } \\
\text { complications, surgical time, } \\
\text { blood loss, or outcomes. }\end{array}$ \\
\hline Teli et al. & $\begin{array}{l}\text { MED vs } \\
\text { microdiscectomy } \\
\text { vs open } \\
\text { discectomy }\end{array}$ & 70 vs 72 vs 70 & $\begin{array}{l}\text { MED associated with more frequent } \\
\text { severe complications (dural leak, nerve } \\
\text { root injury recurrent herniation) } \\
\text { compared to Microdiscectomy or Open. } \\
\text { Higher cost per case for MED. } \\
\text { Longer operative time with MED. }\end{array}$ & $\begin{array}{l}\text { No significant difference in VAS } \\
\text { scores for leg and back pain, } \\
\text { ODI, SF-36, hospital stay. }\end{array}$ \\
\hline $\begin{array}{l}\text { Kamper } \\
\text { et al. }\end{array}$ & $\begin{array}{l}\text { MED vs } \\
\text { microdiscectomy }\end{array}$ & $\begin{array}{l}\text { 4,472 } \\
\text { (meta-analysis) }\end{array}$ & $\begin{array}{l}\text { Low evidence of shorter hospital stay } \\
\text { in MED. }\end{array}$ & $\begin{array}{l}\text { Moderate to low evidence to } \\
\text { suggest no difference in } \\
\text { clinical outcomes, } \\
\text { complications or reoperations } \\
\text { between MED vs open } \\
\text { discectomy. }\end{array}$ \\
\hline $\begin{array}{l}\text { Righesso } \\
\text { et al. }\end{array}$ & $\begin{array}{l}\text { MED vs open } \\
\text { discectomy }\end{array}$ & 19 vs 21 & $\begin{array}{l}\text { Less pain at } 12 \mathrm{hr} \text { post operation with } \\
\text { Open discectomy. } \\
\text { Longer operative time with MED. } \\
\text { 2-hrs shorter hospital stay with MED. }\end{array}$ & $\begin{array}{l}\text { No significant difference in } \\
\text { ODI, change in motor/sensory } \\
\text { deficits or VAS for pain } \\
\text { (except at } 12 \mathrm{hr} \text { after surgery) }\end{array}$ \\
\hline Garg et al. & $\begin{array}{l}\text { MED vs open } \\
\text { discectomy }\end{array}$ & 55 vs 57 & $\begin{array}{l}\text { Longer operative time with MED but lesser } \\
\text { blood loss and shorter hospital stay. }\end{array}$ & $\begin{array}{l}\text { No significant difference in } \\
\text { ODI, low back pain and } \\
\text { complications rate }\end{array}$ \\
\hline $\begin{array}{l}\text { Cochrane } \\
\text { review } \\
\text { by } \\
\text { rasouli } \\
\text { et al. }\end{array}$ & $\begin{array}{l}\text { MED vs } \\
\text { microdiscectomy } \\
\text { vs open } \\
\text { discectomy }\end{array}$ & 1,172 & $\begin{array}{l}\text { Open: less leg pain at } 6 \text { months and } 2 \text { yrs. } \\
\text { Less back pain at } 6 \text { month and } 2 \text { yrs. } \\
\text { Higher quality of life score on SF- } 36 \\
\text { Subclasses after } 6 \text { months. } \\
\text { Lower risk of recurrent disc herniation but } \\
\text { higher risk of surgical site infection. } \\
\text { MED associated with shorter hospital stay. }\end{array}$ & $\begin{array}{l}\text { No difference in ODI, } \\
\text { persistence of neurological } \\
\text { deficits, sciatica frequency } \\
\text { index. }\end{array}$ \\
\hline $\begin{array}{l}\text { Gempt } \\
\text { et al. }\end{array}$ & Open vs MED & 60 & $\mathrm{n} / \mathrm{a}$ & $\begin{array}{l}\text { No significant difference in } \\
\text { VAS, ODI, SF-36 form. }\end{array}$ \\
\hline Lau et al. & $\begin{array}{l}\text { MED vs open } \\
\text { discectomy }\end{array}$ & 20 vs 25 & $\mathrm{n} / \mathrm{a}$ & $\begin{array}{l}\text { No difference in pain, } \\
\text { complications, blood loss, } \\
\text { operative time, length of } \\
\text { hospital stay, and neurological } \\
\text { function. }\end{array}$ \\
\hline
\end{tabular}


group in which 5 patients showed post-operative CSF wound leak. Residual disc with persistent leg pain requiring reoperation was seen in 4 cases in MED and 2 cases in MLD group. 11 patients had wound infection in MLD group out of which 3 patients developed post-operative discitis. There were 2 cases of nerve root injury which led to postoperative extensor hallucis longus (EHL) weakness in both the groups, which recovered completely in 2 months (Table 4).

\section{DISCUSSION}

Kambin and Savitz ${ }^{10)}$ in 1973, introduced the concept of endoscopic lumbar discectomy. The microsurgical discectomy was introduced by Yasargal $^{22)}$ and Casper ${ }^{4)}$ in 1977 which became the gold standard treatment for lumbar disc herniation. In 1997, Foley and Smith ${ }^{5}$ introduced an operated endoscope with tubular retractors system termed as "Endoscopic Discectomy" and in 2003, introduced a microscope also, called "MED-micro-endoscopic discectomy" and described it as a trans-muscular technique to gain access to the disc via dilators of increasing diameter and a tubular retractor, whereby simultaneous visualization and removal of disc can be performed through a single portal.

There are various studies which compared the outcomes of MED vs MLD showing superiority of MED over MLD in terms of infection, mean return to work and hospital stay. However, these claims have a little support in the literature to justify the adoption of MED over standard MLD and are still controversial.

We observed difference in the blood loss between 2 groups with less blood loss in MED group similar to other studies ${ }^{7,8,17)}$. However, the observed difference in estimated blood loss between the groups would seem unlikely to affect the need for a transfusion (a rare event in lumbar disc surgery). There was no significant difference in operative time between both the groups.

The study proved equal efficacy of both procedures in reducing leg pain as highlighted by other studies ${ }^{8,717,21)}$. However, there was a greater reduction in back pain in MED group at 2 weeks follow-up but it was not significant. The reason could be less tissue trauma due to dilation and thus preservation of the paraspinous muscles ${ }^{21)}$, electromyography study done by Schick et al. is a proof of this phenomenon ${ }^{18)}$. Brock ${ }^{3)}$ reported less consumption of analgesic in patients operated by trans-muscular technique. However, some other studies differ on this fact. Arts $^{2)}$ and Anderson ${ }^{1)}$ described increased back pain in MED as compared to MLD group. Teli et al. ${ }^{21)}$ did not find any difference in postoperative back pain between micro, micro-endoscopic, and open discectomy (Table 5).

Hospital stay in MED group was less as compared to MLD but was not significant. The results differed in the study by Teli et al. ${ }^{21)}$ (2.3 days in MED vs. 2.1 days in MLD). Prolonged hospital stay in MLD group can be attributed to delayed postoperative recovery due to increased back pain. Return to work was faster in MED group as compared to MLD group with less hospital readmission rates in MED. This might be attributed to no postoperative infection or CSF leakage in MED group.

Various studies have reported the occurrence of dural tear in 4-20\% after MED ${ }^{6,15)}$ while the incidence in MLD is comparatively less. We found 5.5\% dural tear in MED and 4.6\% in MLD which is similar to other studies. Dural repair was done in only 2 cases in MLD group as tear was large and central. However, management of dural tear in MED cases does not required any closure or application of fibrin glue because soon after the removal of tubular retractor (within 5-10 min), the tissues fall back, creates the physical barrier to the hydrostatic pressure of the intradural space and the small gap is closed so well that there is no space for CSF to accumulate ${ }^{14)}$.

Postoperative symptomatic CSF leak through wound was seen in 5 cases in MLD group which was managed conservatively however, none of them developed postoperative pseudo meningoceles.

None of the patients in MED group had deep infection as the potential dead space at risk for infection is reduced in MIS surgery with the use of tubular retractor. This reduction may help prevent postoperative hematomas or seromas that may lead to infection. The tubular retractor also physically blocks the local contamination of deep tissue by surface skin flora and only permits the use of surgical instruments. We found that the patients who underwent MED had similar outcomes as those who underwent MLD however, the ubiquitous nature of the open approach avoids the steep learning curve of MIS techniques, which can be associated with unfavourable outcomes and increased risk of complications particularly early on and when extension to open is needed.

\section{CONCLUSION}

Lumbar discectomy either MED or MLD are very safe and effective means of treating disc herniation related sciatic pain. Patients who underwent minimally invasive tubular micro-endoscopic discectomy were found to have similar outcomes as those who underwent micro-lumbar discectomy. However, given the learning curve associated with the introduction of minimally invasive approaches to clinical practice, these modest clinical benefits probably do not warrant the transition from a standard microsurgical approach to a minimally invasive approach.

\section{REFERENCES}

1. Anderson PA: Tubular discectomy resulted in greater leg and back pain and a lower rate of recovery than conventional microdiscectomy for sciatica. J Bone Joint Surg Am 92:475, 2010

2. Arts MP, Brand R, van den Akker ME, Koes BW, Bartels RH, Peul WC, et al: Tubular diskectomy vs conventional microdiskectomy for sciatica: A randomized controlled trial. Jama 302: 149-158, 2009

3. Brock M, Kunkel P, Papavero L: Lumbar microdiscectomy: Subperiosteal versus transmuscular approach and influence on the 
early postoperative analgesic consumption. Eur Spine J 17:518522, 2008

4. Caspar W: A new surgical procedure for lumbar disc herniation causing less tissue damage through a microsurgical approach. In Lumbar Disc Adult Hydrocephalus. Springer, Berlin, Heidelberg 74-80, 1977

5. Foley KT, Smith MM: Microendoscopic discectomy. Tech Neurosurg 3:301-307, 1997

6. Fourney DR, Dettori JR, Norvell DC, Dekutoski MB: Does minimal access tubular assisted spine surgery increase or decrease complications in spinal decompression or fusion? Spine 35:5765,2010

7. Garg B, Nagraja UB, Jayaswal A: Microendoscopic versus open discectomy for lumbar disc herniation: A prospective randomised study. J Orthop Surg 19(1):30-34, 2011

8. Harrington JF, French P: Open versus minimally invasive lumbar microdiscectomy: Comparison of operative times, length of hospital stay, narcotic use and complications. Minimally Invasive Neurosurg 51:30-35, 2008

9. Javedan S, Sonntag VK: Lumbar disc herniation: Microsurgical approach. Neurosurgery 52(1):160-164, 2003

10. Kambin P, Savitz MH: Arthroscopic microdiscectomy: An alternative to open disc surgery. The Mount Sinai Journal of Medicine, New York 67(4):283, 2000

11. Katayama Y, Matsuyama Y, Yoshihara H, Sakai Y, Nakamura $\mathrm{H}$, et al: Comparison of surgical outcomes between macro discectomy and micro discectomy for lumbar disc herniation: A prospective randomized study with surgery performed by the same spine surgeon. Clinical Spine Surgery 19(5):344-347, 2006

12. Konstantinou K, Dunn KM: Sciatica: Review of epidemiological studies and prevalence estimates. Spine 33(22):2464-2472, 2008

13. Kotil K, Tunckale T, Tatar Z, Koldas M, Kural A, Bilge T: Serum creatine phosphokinase activity and histological changes in the multifidus muscle: A prospective randomized controlled comparative study of discectomy with or without retraction. Journal of Neurosurgery: Spine 6(2):121-125, 2007
14. Kulkarni AG, Bassi A, Dhruv A: Microendoscopic lumbar discectomy: Technique and results of 188 cases. Indian J Orthop 48:81-87, 2014

15. Matsumoto M, Hasegawa T, Ito M, Aizawa T, Konno S, Yamagata $\mathrm{M}$, et al: Incidence of complications associated with spinal endoscopic surgery: Nationwide survey in 2007 by the Committee on Spinal Endoscopic Surgical Skill Qualification of Japanese Orthopaedic Association. J Orthop Sci 15:92-96, 2010

16. McGirt MJ, Ambrossi GL, Datoo G, Sciubba DM, et al: Recurrent disc herniation and long-term back pain after primary lumbar discectomy: Review of outcomes reported for limited versus aggressive disc removal. Neurosurgery 64(2):338-345, 2009

17. Porchet F, Bartanusz V, Kleinstueck FS, Lattig F, et al: Microdiscectomy compared with standard discectomy: An old problem revisited with new outcome measures within the framework of a spine surgical registry. European Spine Journal 18(3):360-366, 2009

18. Schick U, Döhnert J, Richter A, König A, Vitzthum H: Microendoscopic lumbar discectomy versus open surgery: An intraoperative EMG study. European Spine Journal 11(1):20-26, 2002

19. Shin DA, Kim KN, Shin HC: The efficacy of microendoscopic discectomy in reducing iatrogenic muscle injury. Journal of Neurosurgery: Spine 8(1):39-43, 2008

20. Tait MJ, Levy J, Nowell M, Pocock C, Petrik V, et al: Improved outcome after lumbar microdiscectomy in patients shown their excised disc fragments: a prospective, double blind, randomised, controlled trial. Journal of Neurology, Neurosurgery \& Psychiatry 80(9):1044-1046, 2009

21. Teli M, Lovi A, Brayda-Bruno M, Zagra A, et al: Higher risk of dural tears and recurrent herniation with lumbar micro-endoscopic discectomy. Eur Spine J 19:443-450, 2010

22. Yasargil MG: Microsurgical operation of herniated lumbar disc. In Lumbar Disc Adult Hydrocephalus. Springer, Berlin, Heidelberg pp81, 1977 